\title{
Economic Analysis of Vegetable Production in Nagrota Bagwan Block of Kangra District of Himachal Pradesh, India
}

\author{
Rashmi $^{1 *}$, M. S. Pathania ${ }^{2}$, Anwesha Deo ${ }^{1}$ and H. P. Singh ${ }^{1}$ \\ ${ }^{1}$ Department of Agricultural Economics, Institute of Agricultural Sciences \\ BHU, Varanasi-221005, India \\ ${ }^{2}$ Department of Agricultural Economics, Extension Education and Rural Sociology \\ CSKHPKV, Palampur, Himachal Pradesh-176062, India \\ *Corresponding author
}

\section{A B S T R A C T}

\begin{tabular}{|l|}
\hline Ke y w or d s \\
Economic analysis, \\
Vegetable \\
production, \\
B-C ratio \\
\hline Article Info \\
\hline Accepted: \\
05 February 2020 \\
Available Online: \\
10 March 2020
\end{tabular}

\section{Introduction}

The vegetables are an important article of daily human diet and are recognized all over the world. Vegetables are the important sources of food and nutritional security.Significant achievements have been obtained in terms of production, which has increased to 184 million tons during 2017-18 from 169 million tons during 2015-16. Agriculture occupies an important position in Himachal Pradesh. It provides direct employment to 62 per cent of the working population and contributes about 22 per cent 
to gross state domestic product. The land holding size has decreased overtime due to division of family. About 88 per cent land holding are marginal and small and growing of food grain crops is not profitable. Vegetable production is labour intensive, short duration and more profitable which fits well in the marginal and small farm production systems. It provides regular work throughout the year to the vegetable growers and his family labours. It is therefore, expected that vegetable production would augment income and employment opportunities for small and marginal farmers of the state and also accelerating the growth of state domestic product. The profitability of vegetable production is dependent on the optimum use of inputs like seeds, fertilizers, plant protection chemicals, machines and labour. The cost of different input use in production and sale prices of vegetables play an important role in the profit earned from vegetables cultivation. Therefore, it is necessary to study the different economic aspects of vegetables farming. Keeping in view the present study was carried to study the economics of major vegetables grown in Nagrota Bagwan block of Kangra district of Himachal Pradesh.

\section{Materials and Methods}

The present study was conducted in Nagrota Bagwan block of Kangra district. The farmers of this block grow vegetable crops on commercial scale so it was purposively selected. Three stage random sampling technique was used for the present study. At the first stage, 3 gram panchayats growing vegetables were selected randomly from the selected block growing vegetable crops. At the second stage, 2 villages were selected at random from each gram panchayat. Ten household were selected randomly from each village. The final sample consisted of 60 households.

\section{Cost concepts}

Cost concepts defined by Commission for Agricultural Costs and Prices (CACP) in India, were used to calculate cost of vegetable cultivation.

COST $\mathbf{A}_{1}=$ All The variable costs excluding family labour cost and including depreciation. The items covered in cost A1 was 1 . Cost of hired human labour. 2. Cost of hired bullock labour. 3. Cost of owned bullock labour. 4.Cost of owned machinery. 5. Cost of hired machinery. 6. Cost of fertilizer. 7. Cost of manure. 8. Cost of seed (owned /purchased) 9. Cost of plant protection chemicals. 10. Irrigation charges11. Land revenue and other taxes. 12. Depreciation of farm machinery, equipments and farm buildings. 13. Interest on owned working capital. 14. Interest payment on crop loan. 15. Miscellaneous expenses.

Cost $\mathbf{A}_{2}$ : Cost $A_{1}+$ rent paid for leased in land.

$\operatorname{Cost} B_{1}$ : Cost $A_{1}+$ interest on value of owned capital assets (excluding land).

$\operatorname{Cost} \mathbf{B}_{2}$ : Cost $\mathrm{B}_{1}+$ rental value of owned land + rent paid for leased-in land.

Cost $\mathbf{C}_{1}$ : Cost $\mathrm{B}_{1}+$ imputed value of family labour.

Cost $\mathbf{C}_{2}$ : Cost $\mathrm{B}_{2}+$ imputed value of family labour.

Cost $C_{3}$ : Cost $C_{2}+10 \%$ of Cost $C_{2}$ on account of managerial functions performed by the farmer.

\section{Results and Discussion}

\section{Component wise cost of cultivation of vegetable crops}

The component wise costs incurred in the cultivation of kharif and rabi vegetable crops is given in the table 1 table 2 respectively. 
Table.1 Component wise cost of cultivation of kharif vegetable crops on sample farms (Rs/ha)

\begin{tabular}{|c|c|c|c|c|c|}
\hline Particulars & Okra & Brinjal & Cucumber & Bottle gourd & Bitter Gourd \\
\hline \multicolumn{6}{|l|}{ Variable costs } \\
\hline Seed & $19491(13.50)$ & 1880(1.69) & 19613(14.59) & $9690(10.04)$ & $12533(11.80)$ \\
\hline FYM & $5000(3.46)$ & $4000(3.60)$ & $10000(7.44)$ & $3636(3.77)$ & $4000(3.77)$ \\
\hline Fertilizers & $2185(1.51)$ & 1713(1.54) & $1440(1.07)$ & $1204(1.25)$ & $1204(1.13)$ \\
\hline Plant protection & $3818(2.65)$ & $3091(2.78)$ & $3245(2.41)$ & $2182(2.26)$ & $1909(1.80)$ \\
\hline Human labour & $81,000(56.12)$ & $72,000(64.80)$ & $78,000(58.02)$ & $60,000(62.22)$ & $66,000(62.16)$ \\
\hline Hired labour & $33000(22.86)$ & $33000(29.70)$ & $36000(26.78)$ & $21000(21.77)$ & $33000(31.08)$ \\
\hline Family labour & $48000(33.26)$ & $39000(35.10)$ & $42000(31.24)$ & $39000(40.43)$ & $33000(31.08)$ \\
\hline Tractor / power tiller & $11086(7.68)$ & $10500(9.45)$ & $2727(2.03)$ & $2727(2.83)$ & $2727(2.57)$ \\
\hline Irrigation & 2182(1.51) & 2182(1.96) & $2727(2.03)$ & $3273(3.39)$ & $1909(1.80)$ \\
\hline Interest on working & $3069(2.13)$ & $2255(2.03)$ & $3030(2.25)$ & $1748(1.81)$ & 2291(2.16) \\
\hline Sub-Total & $127832(88.57)$ & $97620(87.87)$ & $120783(89.85)$ & $84460(87.55)$ & $92573(87.17)$ \\
\hline \multicolumn{6}{|l|}{ Fixed costs } \\
\hline Rental value of land & $2300(1.59)$ & 1955(1.76) & $2864(2.13)$ & 1391(1.44) & $2100(1.98)$ \\
\hline Land revenue & $47(0.03)$ & $36(0.03)$ & $26(0.02)$ & $11(0.01)$ & $14(0.01)$ \\
\hline Depreciation & 10764(7.46) & $8678(7.81)$ & $7920(5.89)$ & $8291(8.59)$ & $8460(7.97)$ \\
\hline Interest on fixed capital & $3391(2.35)$ & $2809(2.53)$ & $2829(2.10)$ & $2315(2.40)$ & $3047(2.87)$ \\
\hline Sub-Total & $16502(11.43)$ & $13478(12.13)$ & $13639(10.15)$ & $12007(12.45)$ & $13621(12.83)$ \\
\hline Total Cost & $144334(100.00)$ & $111098(100.00)$ & $134422(100.00)$ & $96467(100.00)$ & 106194(100.00) \\
\hline Cost of production/kg & 12.00 & 5.34 & 7.86 & 4.57 & 5.96 \\
\hline
\end{tabular}

Figures in the parentheses indicates the percentage to the total cost. 
Table.2 Component wise cost of cultivation of rabi vegetable crops on sample farms (Rs/ha)

\begin{tabular}{|c|c|c|c|c|c|}
\hline Particulars & Cauliflower & Cabbage & Potato & Radish & Onion \\
\hline \multicolumn{6}{|l|}{ Variable costs } \\
\hline Seed & $17746(11.99)$ & $10025(7.85)$ & $61028(30.85)$ & $3260(3.25)$ & $7481(5.99)$ \\
\hline FYM & $7500(5.07)$ & $7500(5.87)$ & $3918(1.98)$ & $4000(3.99)$ & $4000(3.20)$ \\
\hline Fertilizers & $2836(1.92)$ & $2127(1.67)$ & $1829(0.92)$ & $1512(1.51)$ & $1527(1.22)$ \\
\hline Plant protection & $2182(1.47)$ & $1364(1.07)$ & $2882(1.45)$ & $2182(2.18)$ & $2182(1.75)$ \\
\hline $\begin{array}{l}\text { Human labour } \\
\text { Hired labour } \\
\text { Family labour }\end{array}$ & $\begin{array}{l}87,000(58.78) \\
39000(26.35) \\
48000(32.43)\end{array}$ & $\begin{array}{l}81,000(63.43) \\
36000(28.19) \\
45000(35.24)\end{array}$ & $\begin{array}{l}1,01,000 \\
(48.53) \\
45000(22.75) \\
56000(25.78)\end{array}$ & $\begin{array}{l}66,000(65.86) \\
24000(23.95) \\
42000(41.91)\end{array}$ & $\begin{array}{l}84,000(67.22) \\
36000(28.81) \\
48000(38.41)\end{array}$ \\
\hline Tractor / power tiller & $11086(7.49)$ & $7500(5.87)$ & $11250(5.69)$ & $7500(7.48)$ & $11250(9.00)$ \\
\hline Irrigation & $3273(2.21)$ & $2727(2.14)$ & $1400(0.70)$ & $2727(2.72)$ & $1091(0.87)$ \\
\hline Interest on working & $3345(2.26)$ & $2690(2.11)$ & $5092(2.57)$ & $1807(1.80)$ & $2541(2.03)$ \\
\hline Sub-Total & 134968(91.19) & 114933(90.00) & $183399(92.71)$ & $88988(88.81)$ & $114072(91.28)$ \\
\hline \multicolumn{6}{|l|}{ Fixed costs } \\
\hline Rental value of land & $2445(1.65)$ & $2369(1.86)$ & $3242(1.64)$ & $2240(2.24)$ & $2058(1.65)$ \\
\hline Land revenue & $47(0.03)$ & $47(0.04)$ & $21(0.01)$ & $15(0.01)$ & $13(0.01)$ \\
\hline Depreciation & $7704(5.20)$ & $7685(6.02)$ & $7040(3.56)$ & $6458(6.45)$ & $6124(4.90)$ \\
\hline $\begin{array}{l}\text { Interest on fixed } \\
\text { capital }\end{array}$ & $2844(1.92)$ & 2664(2.09) & $4122(2.08)$ & $2502(2.50)$ & $2704(2.16)$ \\
\hline Sub-Total & $13039(8.81)$ & $12765(10.00)$ & $14424(7.29)$ & $11215(11.19)$ & $10898(8.72)$ \\
\hline Total Cost & $148008(100.00)$ & $127698(100.00)$ & $\begin{array}{l}197824 \\
(100.00)\end{array}$ & 100203(100.00) & $124970(100.00)$ \\
\hline Cost of production/kg & 8.18 & 7.98 & 6.63 & 6.34 & 7.31 \\
\hline
\end{tabular}

Figures in the parentheses indicates the percentage to the total cost. 
Table.3 Costs and returns of kharif vegetables (Rs/ha)

\begin{tabular}{|c|c|c|c|c|c|}
\hline Particulars & Okra & Brinjal & Cucumber & Bottle gourd & Bitter gourd \\
\hline $\operatorname{Cost} A_{1}$ & 90643 & 67334 & 86729 & 53762 & 68047 \\
\hline $\operatorname{Cost} \mathrm{A}_{2}$ & 90634 & 67334 & 86729 & 53762 & 68047 \\
\hline Cost $B_{1}$ & 94034 & 70143 & 89558 & 56076 & 71094 \\
\hline Cost $B_{2}$ & 96334 & 72098 & 92422 & 57467 & 73194 \\
\hline Cost $C_{1}$ & 142034 & 109143 & 131558 & 95076 & 104094 \\
\hline Cost $C_{2}$ & 144334 & 111098 & 134422 & 96467 & 106194 \\
\hline Cost $C_{3}$ & 158976 & 122456 & 147864 & 106114 & 116813 \\
\hline Gross returns & 215280 & 177370 & 217500 & 168800 & 155750 \\
\hline Net returns over & & & & & \\
\hline $\operatorname{Cost} A_{1}$ & 124637 & 110035 & 130771 & 115038 & 87703 \\
\hline $\operatorname{Cost} \mathrm{A}_{2}$ & 124637 & 110035 & 130771 & 115038 & 87703 \\
\hline Cost $B_{1}$ & 121246 & 107226 & 127942 & 112724 & 84656 \\
\hline $\operatorname{Cost} B_{2}$ & 118946 & 105272 & 125078 & 111333 & 82556 \\
\hline $\operatorname{Cost} C_{1}$ & 73246 & 68226 & 85942 & 73724 & 51656 \\
\hline Cost $C_{2}$ & 70946 & 66272 & 83078 & 72333 & 49556 \\
\hline $\operatorname{Cost} \mathrm{C}_{3}$ & 56304 & 54913 & 69636 & 62686 & 38937 \\
\hline B-C ratio & 1.35 & 1.45 & 1.50 & 1.60 & 1.33 \\
\hline
\end{tabular}

Table.4 Costs and returns of rabi vegetables (Rs/ha)

\begin{tabular}{|c|c|c|c|c|c|}
\hline Particulars & Cauliflower & Cabbage & Potato & Radish & Onion \\
\hline $\operatorname{Cost} \mathbf{A}_{1}$ & 94719 & 77665 & 139460 & 53461 & 72209 \\
\hline $\operatorname{Cost} A_{2}$ & 94719 & 77665 & 139460 & 53461 & 72209 \\
\hline Cost $B_{1}$ & 97562 & 80329 & 143582 & 55963 & 74912 \\
\hline $\operatorname{Cost} B_{2}$ & 100008 & 82698 & 146824 & 58203 & 76970 \\
\hline Cost $C_{1}$ & 145562 & 125329 & 194582 & 97963 & 122912 \\
\hline $\operatorname{Cost} \mathrm{C}_{2}$ & 148008 & 127698 & 197824 & 100203 & 124970 \\
\hline Cost $C_{3}$ & 162808 & 140468 & 217606 & 110223 & 137467 \\
\hline Gross returns & 288800 & 200000 & 242350 & 131250 & 196150 \\
\hline Net returns over & & & & & \\
\hline $\operatorname{Cost} A_{1}$ & 194081 & 122335 & 102890 & 77789 & 123941 \\
\hline $\operatorname{Cost} A_{2}$ & 194081 & 122335 & 102890 & 77789 & 123941 \\
\hline $\operatorname{Cost} B_{1}$ & 191238 & 119671 & 98768 & 75287 & 121238 \\
\hline $\operatorname{Cost} B_{2}$ & 188792 & 117302 & 95526 & 73047 & 119179 \\
\hline $\operatorname{Cost} C_{1}$ & 143238 & 125329 & 47768 & 33287 & 73238 \\
\hline Cost $C_{2}$ & 140792 & 72302 & 44526 & 31047 & 71179 \\
\hline Cost $C_{3}$ & 125992 & 59532 & 24744 & 21027 & 58682 \\
\hline B-C ratio & 1.78 & 1.40 & 1.11 & 1.19 & 1.43 \\
\hline
\end{tabular}


It is evident from table 1 that the total variable cost per hectare was highest in okra (Rs $1,27,832$ ), followed by cucumber (Rs 1,20,783), brinjal (Rs 97,620), bitter gourd (Rs 92,573) and bottle gourd (Rs 84,460). The proportion of labour cost to the total cost accounted for more than 50 per cent in different kharif vegetables followed by seed, tractor and FYM. In case of material cost, seed was the major component of the cost which accounted for more than 10 per cent of the total cost except in brinjal $(1.63 \%)$. The expenditure on FYM, fertilizers, plant protection and irrigation was to the extent of 1 to 7 per cent of total cost for different kharif vegetables. Among the material cost, the proportion of cost was noted highest in FYM and lowest in irrigation in almost all the vegetables. The cost of production was highest in case of cucumber ( Rs $7.86 / \mathrm{kg}$ ) and lowest in bitter gourd (Rs 5.96/kg).

\section{Costs and returns estimation of vegetable crops}

The cost and returns on CACP concepts for kharif and rabi vegetables is presented in Table $3 \& 4$ respectively. It was observed from the table that among major vegetable crops grown on hectare basis, okra (Rs 158976)) and potato (Rs.217606) showed the highest Cost $\left(\mathrm{C}_{3}\right)$ in kharif and rabi season respectively. The net returns were positive for different kharif and rabi crops even when the cost of family labour was included. The net returns obtained from different kharif vegetables revealed that highest net returns over cost $\mathrm{C}_{3}$ were from cucumber (Rs 69636) followed by bottle gourd (Rs 68686), okra (Rs 56304), brinjal (Rs 54913) and bitter gourd (Rs 38937). Among rabi vegetable crops, cauliflower (Rs 125992) showed the highest Cost $\mathrm{C}_{3}$ per hectare followed by cabbage (Rs 59532), onion (Rs 58682), potato (Rs 24744) and radish (Rs 21027). The B-C ratio was also estimated for different vegetable crops. The ratio varied from 1.33 to 1.60 in kharif to 1.11 to 1.78 in rabi for different vegetables. The output-input ratio was greater than one for all the major vegetable crops in the study area indicating that growing of vegetables is a profitable business and farmers are earning good profit from vegetable farming.

From the above cost and return analysis, it can be concluded that vegetable cultivation is a profitable business for the farmers of the study area as it gives higher returns in shorter period. Amongst the expenditure incurred on different inputs, human labour accounted for more than 50 per cent of the total cost. In the material cost, seed was the major component in general, followed by FYM and fertiliser. The different costs were also estimated as per the CACP cost concepts. The net returns were positive for different kharif and rabi crops even when the cost of family labour was included. The B-C ratio for all the vegetable crops was greater than one indicating that vegetable growing is a profitable.

\section{References}

Bezbaruah M.P. and Roy N. 2002. Factors affecting cropping intensity and use of fertilizers and high yielding variety seeds in Barak Valley. Indian Journal of Agricultural Economics 57(2): 169179

Chowdhuri NY, Haque S, Shammi SA, Jannat A, Sannyashi PR.2014.Profitability analysis of winter vegetables production in a selected area of Narshingdi district in Bangladesh. Progressive Agriculture 25: 47-53

Singla R, Chahal SS and Kataria P. 2006. Economics of production of green peas in Punjab. Agricultural Economics Research Review 19:237-250. 


\section{How to cite this article:}

Rashmi, M. S. Pathania, Anwesha Deo and Singh, H. P. 2020. Economic Analysis of Vegetable Production in Nagrota Bagwan Block of Kangra District of Himachal Pradesh. Int.J.Curr.Microbiol.App.Sci. 9(03): 376-382. doi: https://doi.org/10.20546/ijcmas.2020.903.044 